\title{
Clinicopathological Study of Supraglottic Carcinoma of Larynx
}

\author{
Alam MM ${ }^{1}$, Hossain $\mathrm{MZ}^{2}$, Khan MSBS 3
}

DOI: https:/ / doi.org/ 10.3329/ jafmc.v15i2.50844

\begin{abstract}
Introduction: Incidence of supraglottic carcinoma is more common which may be related to poor nutrition with personal habit like smoking and chewing habit of betel leaves with various ingredient.
\end{abstract}

Objectives: To find out the incidence, age and sex distribution, occupation and clinical presentation of supraglottic carcinoma of larynx.

Materials and Methods: In this prospective study, 30 patients of supraglottic carcinoma are collected from department of ENT and Head-Neck surgery, Combined Military Hospital, Dhaka from July 2012 to July 2013.

Results: Patients belongs to different age groups, ranging from 40 to 80 years and maximum patients are in 50 to 60 years of age. The male to female ratio is $5: 1$. In this series, majority of patients are smoker (66.66\%). Most of them are from low socio-economic group. The incidence of lymph node involvement is 40\% (12 cases). Maximum number of patients presents with exophytic lesion (60\%). Ulcerative lesions are $26.66 \%$ and infiltrative lesions are $13.33 \%$. Maximum numbers of patients have T2 lesions (80\%). T1 lesions are $20 \%$. In this study all cases are histopathologically confirmed to be squamous cell carcinoma (100\%). In this study, all cases are $M_{0}$ state.

Conclusion: Supraglottic carcinoma occurs between 40-80 years of age, more common in 5th and 6th decades. Chewing betel nut and tobacco should be avoided to reduce the risk of supraglottic carcinoma and early presentation \& diagnosis will improve the prognosis of patients.

Key-Words: Supraglottic carcinoma, Squamous cell carcinoma, exophytic lesion, Smoking.

\section{Introduction}

Laryngeal cancer is the most common head and neck cancer worldwide, but is relatively uncommon in women. However, there is now a trend towards a proportional increase in female numbers compared to males in the UK, probably secondary to increased tobacco consumption 1 .

The demographics and epidemiology of the disease have changed during the past 40 years. Male/female 2,3 incidence has, dropped from 15:1 to now less than 5:1 in 2004. Relative incidence of malignant tumours within the larynx includes: squamous cell carcinoma $>90 \%$ of all laryngeal cancer) and lymphoma (second most common).

Laryngeal cancer represents between $1 \%$ and $2 \%$ of all malignant tumours in the body. Both the general incidence and the incidence by location (supraglottis, glottis, subglottis) have geographic variants. Incidence of supraglottic carcinoma is more common which may be related to poor nutrition with personal habit like smoking and chewing habit of betel leaves with various ingredients ${ }^{4}$.

Other factors associated with increased risk of laryngeal cancer include prolonged exposure to fossil fuels, human papilloma virus infection, chronic gastro-esophageal reflux, passive smoking, and occupational exposure to substances like- asbestos, wood, cement, solvent and nickel. Those working in the railway and timber industry, sheet metal worker, grinding wheel operators, and car mechanics are also said to have a higher incidence of laryngeal cancer. High dietary intake of fruits and vegetables is associated with a decreased incidence of laryngeal cancer, probably because of a protective effect related to high contents of vitamins $\mathrm{A}$ and $\mathrm{C}^{4}$.

The symptom pattern of supraglottic carcinoma are altogether more diffuse ${ }^{5}$. Clinically supraglottic carcinoma usually presents with progressive and unremitting dysphonia followed possibly by difficulty in respiration, difficulty in swallowing, pain in the throat often radiating to the homolateral ear, neck masses and rarely debilitation. The important factors influencing survival rate are the site of primary lesion, local infiltration, level of cellular differentiation and regional metastasis. Survival decreases by $40 \%$ with the regional metastasis ${ }^{6}$. Referred otalgia is caused by Arnolds nerve, the vagal branch that supplies part of ear sensation. Bulky tumours of the epiglottis often present with a hot potato or muffled voice quality due to airway compromise?. As the supraglottis is rich in lymphatics, incidence of lymphnode metastases and occult metastases is higher here ${ }^{8}$. Few patients present with non-lymphatic distant metastases at the time of diagnosis, most of which occurred in lungs followed by bone, liver and skin incidence of lymph node metastasis from supragiottic cancer is 50 to $60 \%$. There is a significant relationship between the presence of intra tumoral lymphatics and nodal metastasis at presentation and poorly differentiated tumour grade ${ }^{9}$.

\section{Material and Methods}

In this study, 30 patients of supraglottic carcinoma were collected from in-patients Department of Combined Military Hospital, Dhaka. Detail history was taken. General examination and ENT examination were done thoroughly. Examination of neck was done in all patients. The nodal metastases, level of nodal involvement, size of the neck nodes were thoroughly checked. Indirect laryngoscopy, Fibreoptic laryngoscopy and USG and CT scan were done in all cases. FNAC of palpable lymph node was done. Complete blood count, bleeding time, clotting time, serum creatinine, random blood sugar, urine R/E, ECG and X-ray chest P/A view were done. Direct laryngoscopy under $\mathrm{G} / \mathrm{A}$ was done for evaluation of disease and tissue was sent for histopathology for confirmation of malignancy, type of malignancy and histopathological grading. All examination, investigation and operative findings were recorded in data sheet. 


\section{Results}

Table-l: Age distribution $(n=30)$.

\begin{tabular}{|l|c|}
\hline \multicolumn{1}{|c|}{ Age } & No of patients \\
\hline $40-50$ years & 6 \\
\hline $50-60$ years & 15 \\
\hline $60-70$ years & 7 \\
\hline $70-80$ years & 1 \\
\hline$>80$ years & 1 \\
\hline
\end{tabular}

The age of the patient in our study varied from $40 \mathrm{yrs}$ to $80 \mathrm{yrs}$. Maximum number of patients were belonged to $50-60 \mathrm{yrs}(50 \%)$.

Table-II: Sex distribution $(\mathrm{n}=30)$.

\begin{tabular}{|l|c|c|}
\hline Sex & Number of cases & Percentage (\%) \\
\hline Male & 25 & $83 \%$ \\
\hline Female & 5 & $17 \%$ \\
\hline
\end{tabular}

In this study $25(83 \%)$ patients were male and $5(17 \%)$ were female. Thus male to female ratio was 4.8:1.

Table-III: Occupation ( $n=30)$.

\begin{tabular}{|l|c|c|}
\hline \multicolumn{1}{|c|}{ Occupation } & Number of cases & Percentage (\%) \\
\hline Cultivation & 13 & $43.33 \%$ \\
\hline Service & 4 & $13.33 \%$ \\
\hline Labour & 4 & $13.33 \%$ \\
\hline Business man & 2 & $6.66 \%$ \\
\hline House Wife & 2 & $6.66 \%$ \\
\hline Teaching & 2 & $6.66 \%$ \\
\hline Shop Keeper & 3 & $10 \%$ \\
\hline
\end{tabular}

$13(43.33 \%)$ patients of this study were cultivators and the next common occupations of the patients were service and labour

Table-IV: Socio-economical condition $(n=30)$.

\begin{tabular}{|l|c|c|}
\hline Soclo-economic status & Number of cases & Percentage (\%) \\
\hline Poor Class & 17 & $56.66 \%$ \\
\hline Medium Class & 11 & $36.66 \%$ \\
\hline Higher Class & 2 & $6.66 \%$ \\
\hline
\end{tabular}

Most of the patients belonged to poor socio-economic class (56.66\%).

Table-V: Personal habits of patients with supraglottic carcinoma $(n=30)$.

\begin{tabular}{|l|c|c|}
\hline \multicolumn{1}{|c|}{ Personal habit } & $\begin{array}{c}\text { Number of } \\
\text { patients }\end{array}$ & Percentage \\
\hline Smoking & 20 & 66.66 \\
\hline Chewing leaf and tobacco & 4 & 13.33 \\
\hline $\begin{array}{l}\text { Smoking chewing tobacco and } \\
\text { alcohol }\end{array}$ & 1 & 3.33 \\
\hline Smoking and alcohol & 1 & 3.33 \\
\hline Smoking and chewing tobacco & 4 & 13.13 \\
\hline
\end{tabular}

Smoking was the commonest (66.66\%) personal habit. The other common personal habits were chewing leaf and chewing tobacco.
Table-VI: Incidence of cervical lymph node metastasis $(n=30)$.

\begin{tabular}{|l|c|c|}
\hline $\begin{array}{c}\text { Cervical nodal } \\
\text { metastasis }\end{array}$ & $\begin{array}{c}\text { Number of } \\
\text { patients }\end{array}$ & Percentage \\
\hline Present & 12 & $40 \%$ \\
\hline Absent & 18 & $60 \%$ \\
\hline
\end{tabular}

Out of 30 patients, $12(40 \%)$ had their regional lymph nodes involvement.

Table-VII: Status of involved node $(n=12)$.

\begin{tabular}{|c|c|c|}
\hline \multicolumn{1}{|c|}{ Status } & Number of cases & Percentage \\
\hline N1 & 7 & $58.33 \%$ \\
\hline N2 & 2 & $16.33 \%$ \\
\hline N3 & 3 & $25 \%$ \\
\hline
\end{tabular}

Nodes in N1 stage of involvement were found in most cases (58.33\%)

Table-VIII: Presenting symptoms of supraglottic carcinoma $(n=30)$.

\begin{tabular}{|l|c|c|}
\hline \multicolumn{1}{|c|}{ Symptoms } & No of cases & Percentage (\%) \\
\hline $\begin{array}{l}\text { Cough and } \\
\text { irritation }\end{array}$ & 25 & $83.33 \%$ \\
\hline Dysphagia & 20 & $66.66 \%$ \\
\hline Change of voice & 17 & $56.66 \%$ \\
\hline $\begin{array}{l}\text { Foreign body } \\
\text { sensation }\end{array}$ & 15 & $50.00 \%$ \\
\hline $\begin{array}{l}\text { Respiratory } \\
\text { distress }\end{array}$ & 06 & $20.00 \%$ \\
\hline Neck pain & 06 & $20.00 \%$ \\
\hline Neck sweiling & 16 & $53.33 \%$ \\
\hline Stridor & 04 & $13.33 \%$ \\
\hline Loss of weight & 04 & $13.33 \%$ \\
\hline
\end{tabular}

Most of the patients presented with more than one symptoms and the commonest presenting symptoms of supraglottic carcinoma were cough and irritation (83.33\%) followed by dysphagia (66.66\%) and change of voice (56.66\%). A good number of patients (53.33\%) presented with neck swelling.

\section{Discussion}

Among laryngeal cancers, supraglottic cancer was the commonest in Bangladesh (74.1\%) ${ }^{3}$. This study was carried out to find out the clinic-pathological study of supraglottic carcinoma of larynx. In this study, it was observed that patients belonged to different age groups ranging from 40 to 80 years and maximum patients were in 50 to 60 years of age. Incidence was more in male, smoking was the commonest predisposing factor. The male to female ratio was 5:1. Age and sex incidence was consistent with other studies, $4,8$.

Smoking-especially cigarette smoking and alcohol are indisputable risk factors and act synergistically to increase the risk of malignant transformation ${ }^{5}$. In this study, majority of patients had the habit of smoking (66.66\%) and chewing habit of betel leaves and nuts (13.33\%), but habit of alcohol consumption was less. In study by Quayum $M A^{10}$, habit of smoking was 70\%. Laryngeal carcinoma has marked association with poor socio-economic group. Smoking rates were higher and poor access to healthcare may explain the higher incidence of laryngeal carcinoma in lower socioeconomic classes. In this study most of the patients (56.66\%) were from poor socio- 
economic group, which was about $61.68 \%$ in another study carried out in Bangladesh?2.

Patients presented with one or more symptoms. We found that cough and irritation were the common symptoms (83.33\%) followed by dysphagia (66.66\%), change of voice (56.66\%), neck swelling (53.33\%). Symptoms related to the pain, persistant irritation or sore throats were related to Sidransky D11. Supraglottic carcinoma was of three type's macroscopically ${ }^{12}$. In this study, out of 30 patients, $18(66.66 \%)$ had exophytic, 8 (26.66\%) had ulcerative and $4(13.33 \%)$ had infiltrative growth. Squamous cell carcinoma was the commonest malignant tumour (>90\% of ail laryngeal cancer) ${ }^{1}$. In this study, all cases were histopathologically confirmed to be squamous cell carcinoma.

\section{Conclusion}

1. Supraglottic carcinoma usually occurs between $40-80$ years of age, more common in 5 th and 6 th decades.

2. Patients with supraglottic carcinoma initially present with persistant irritation, pain or sore throat

3. Smoking and chewing (betel nut and tobacco) habits have got relation in the causation of supraglottic carcinoma.

4. Laryngeal carcinoma has got marked association with poor socio economic group.

5. Level-II nodes are frequently involved which are mostly unilateral.

6. If patients present early, staging of carcinoma will not be advanced.

With the above findings, one can clearly say that, chewing betel nut and tobacco should be avoided to reduce the risk of supraglottic carcinoma and early presentation \& diagnosis will improve the prognosis of patients.

\section{References}

1. Birchali MA, Pope L. Tumours of larynx. Gleeson M, ScottBrown's Otorhinolaryngology, Head-Neck Surgery, Great Britain, Hodder Arnold, 2008:2600.
2. Rahman $\mathrm{SH}$, Alauddin $\mathrm{M}$, Ahmed $\mathrm{K}$ et al. Significance of association between sociodemographic features and the site of laryngeai carcinoma, J-Dhaka Med Coll 2003; 12(1):12-21.

3. Adams GL, Maised RH. Malignant tumours of the larynx and hypopharynx. Cummings CW, Otolaryngolagy head and neck surgery, Baltimore Maryland, Elsevier Mosby, 2005:2223-45.

4. Hossain MA et al. Study on topographical distribution of carcinoma larynx, Bangladesh JOtorhinolaryngol 2011; 17(2): 96-103.

5. Zvrko E et al. Risk factor for laryngeai cancer, Arh High Rada toksike! Montenegro 2008; 59:11-8.

6. Rahman MZ. Possible aetiological factors in pharyngeal malignancy-its relation to personal habits, Bangladesh College of Physicians and Surgeons, dissertation, March 1991:24.

7. Lalwani AK. Current diagnosis and treatment in OtolaryngologyHead and neck surgery, 4th ed; Chapter 30, Page 444.

8. Senard RJ, Netter Ville JL, Garrett CG et al. Cancer of larynx. In: Myers EN, Suen JY. Cancer of the head and neck, W.B Saunders Company, Pennsylvania, 1996:381.

9. Raitaila H, Pukander J, Laippala P. Glottic and supraglottic Laryngeai carcinoma: Differences in epidemiology, Clinical characteristics and Prognosis. Acta oto-laryngologica 1999; 119(7):847-51.

10. Quayum MA, Huq AHMZ, Tarafder KH. Pattern of lymph node metastases in supraglottic carcinoma. Bangladesh $\mathrm{J}$ Otorhinolaryngol 2011; 17(2):110-6.

11. Sidransky D. Cancer of the head and neck, Vincent T, Devita, Samuel J.H, Steven A, Rosenberg cancer principles and practice of oncology, Philadelphia, Lippincott Willium and Wilkins, 2005:697-8.

12. Robin PE, Olofsson J. Tumours of the larynx. Scott-Brown's Otolaryngoiogy, Butter Worth-Heinemann, Oxford 6th ed, 5(11):1-43. 